\title{
Possible Traffic Safety Effects of the Implementation of Section Control in Hungary
}

\author{
Zs. Sándor ${ }^{1, *}$ \\ ${ }^{1}$ KTI Institute for Transport Sciences Non-profit Ltd. \\ 1119 Budapest, Than Károly u. 3-5., Hungary \\ *E-mail: zsolt.sandor1@gmail.com
}

\begin{abstract}
This article presents the anticipated safety effects of the implementation of section control in Hungary. The proposed results were originated from international studies and the local circumstances. Effects are depending on the control coverage and the magnitude of the sanctions. Direct (short term benefits) and indirect effects (long term benefits) can be identified. Direct effects are the decreasing of accident numbers, while indirect effects are the decrease of other externalities of transport like environmental impacts. Based on the results the implementation cost of the enforcement system are comparable with the proposed social cost savings coming from the decreasing number of accidents.
\end{abstract}

Keywords: section control; speed enforcement; accident costs; speed control; social costs

\section{Introduction}

This article is the continuation of [1], in which the author estimates the anticipated traffic safety results of section control based on the Hungarian road accident statistics and the international implementation results of the enforcement method. The focus point is the accident prevention. The previously published speeding results provide the actuality of the current material. Personal injury road accident statistics of 2018 were the basis of the estimation made in this study. Only accidents caused by inappropriate speed choice were involved in the analysis because the utmost goal of section control measurement is to reduce the rate and number of speeders. Therefore, the enforcement can mitigate the severity and the number of speeding related road accidents. 
The aim of the article is to present the economic benefits coming from the mitigation of external effects due to the enforcement and estimate this value.

During the selection of the research topic, a dominant aspect was the fact that significant part of the accidents happened on the Hungarian motorways were due to the inappropriate choice of speed. Moreover, the seriousness of the topic has been enhanced by the local accident circumstances - several fatal and serious injury accidents happened on different motorway sections that were affected by diversions and road works. Based on the information provided by the Hungarian Public Road company, only in 2018, 83 accidents were happened in sections affected by maintenance works on motorways. Most of the accidents happen at the beginning of the diversion (road work area): drivers do not give way for each other, or do not consider the warning signals and they hit the work area, or even between the workers. In 2018 distracted drivers hit the road work accessories or infrastructure elements (signs, cones, etc.) or maintenance vehicles 37 times. 9 times these drivers crashed into the Truck Mounted Attenuator. Most of the events were property damage only (PDO) accidents, but serious and fatal accidents also occurred. The current Hungarian traffic behaviour justifies the elaboration of a new and fair speed enforcement system which identifies the speeders.

Figure 1 shows the number of personal injury road traffic accidents in the recent years by taking the outcome of the accidents into consideration [2].

Figure 2 shows the causes of the accidents happened between 2010 and 2018 (items with negligible numbers are marked by * but they are included in the calculations). Significant part of the road traffic accidents is originated in inappropriately selected speeds or specifically to speeding. Only in $201831.4 \%$ (5254 PCS) of the total accidents are caused by the inappropriate speed (exceeding the maximum speed limit - absolute speeding - or selecting a speed that is inappropriate for the actual road conditions - relative speeding) [2]. It can be stated that the highest proportion of accident case is the Incorrect choice of speed. The number of these accidents - resulting in personal injury -has been increased by almost $20 \%$ in the last 8 years.

The structure of the paper is the following. $2^{\text {nd }}$ section contains some professional background of the speed enforcement. $3^{\text {rd }}$ section gives a short summary of the Hungarian traffic safety. The applied analysis methodology is presented in section 4.1, while the results can be found in section 4.2. Information about the further economic effects can be found in the $5^{\text {th }}$ section. Conclusions are summarized in section 6 which closes the paper. 
Zs. Sándor - Acta Technica Jaurinensis, Vol. 13, No. 4, pp. 309-323, 2020

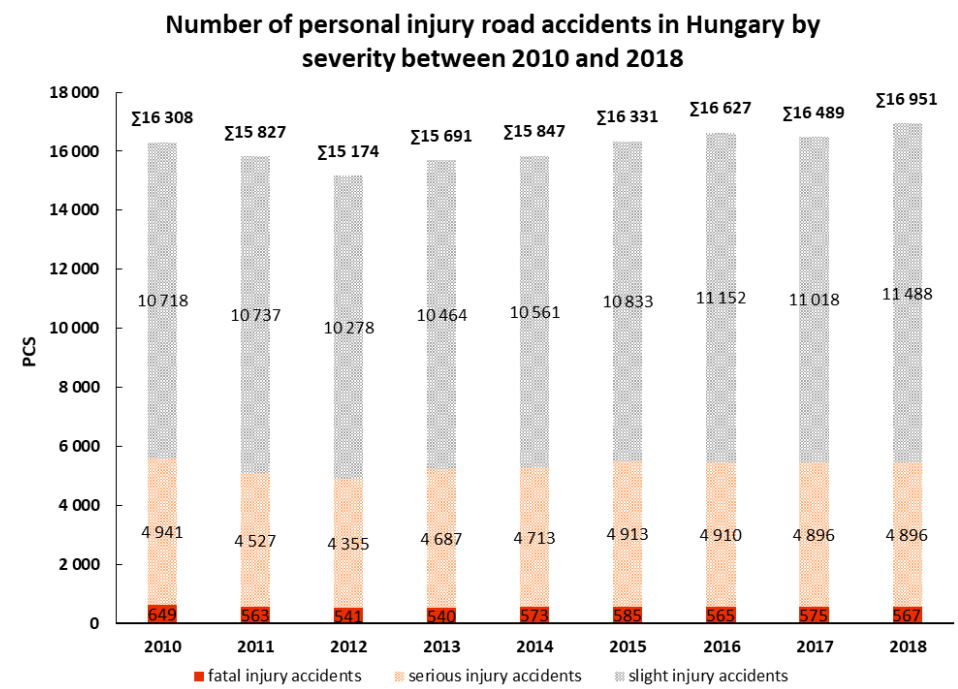

Figure 1. Personal injury road accidents in Hungary between 2010 and 2018.

Number of road accidents with personal injuries in Hungary by accident causes between 2010 and 2018

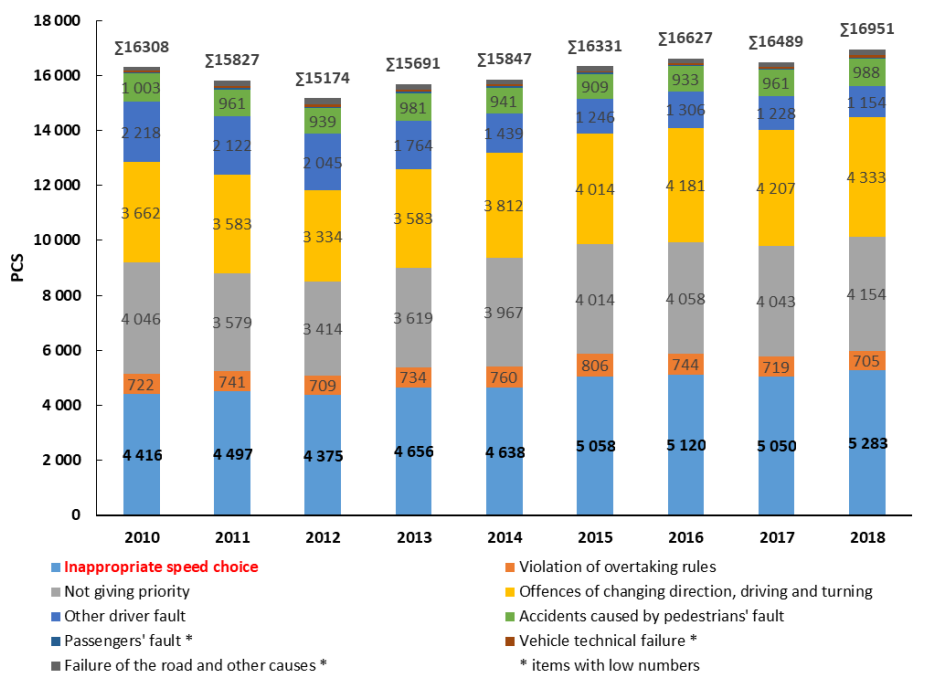

Figure 2. Personal injury road accidents in Hungary by main accident causes between 2010 and 2018. 


\section{Background of section control measurement and its effects}

Based on international studies it can be stated, that section control (with other phrases: section cameras, average speed control, etc.) can significantly mitigate the number of speeders and therefore the measurement can positively influence the traffic safety due to the decreasing number of accidents.

The system calculates the speed of the vehicle between two locations based on the distance of the measurement spots and the elapsed time between the detections. When the passing vehicle on the section has exceeded the speed limit based on the calculation, it may be subject to a penalty procedure for speeding. For reasons of legal certainty, both the measuring devices and the applied calculation method moreover the implementation have to be officially validate. The advantage of the system is the fact that on closed sections (where entry and exit is not possible) user cannot avoid it, thus $100 \%$ of the passing traffic can be detected and controlled. Because of this, the social acceptance of the system is much higher that other (momentaneous / spot / local) speed enforcement solutions.

Section control measurement is a hard (enforcing) measure, because it forces the right driving behaviour by sanctions (penalties, fines, etc.).

International studies in connection with the implementation of section control enforcement systems indicate decreasing accident numbers as a primary effect and pollution mitigation as a secondary effect [3], [4], [5], [6]. The list below contains the main results of international implementations [7], [8], [9].

- The number of fatal and serious accidents significantly decreased (rate of decrease is between $40-65 \%$, but there are sections where the number of fatal accidents decreased by $100 \%$ ).

- Only a negligible proportion of vehicles - less than $1 \%$ - drive faster than the speed limit.

- In case of road works thanks to the section control measurements number of faults is 11 times lower compared to conventional spot speed enforcement acts.

- The method is particularly effective in reducing extreme speeding.

- The benefit-cost ratio (BCR) is high in all cases, it is typically above 5 and 7, but in Australia it is between 10 and 16 .

- Due to the decreasing average speed and the homogenous traffic composition the amount of fuel is reducing, thus traffic-related emission is also reducing (the following list includes the mitigation effects of the measure):

$\begin{array}{ll}\circ & \mathrm{CO}:-15 \% \\ \circ & \mathrm{NO}_{\mathrm{X}}:-5-25 \% \\ \circ & \mathrm{PM}_{10}:-6-35 \%\end{array}$ 
○ $\mathrm{CO}_{2}:-5 \%$.

Section control measurement systems are mainly installed on special road sections like motorways or closed road sections, where speeding is the most common accident risk. The reduction of speeding is the common interest of all stakeholders of the road transport, as a significant proportion of accidents are due to this cause (see Figure 2).

\section{Traffic safety of the Hungarian motorway network}

Figure 3 shows the accident data of the Hungarian motorway network for each year between 2010 and 2018 according to the casualty. Proportions of the given casualty related to all accidents of the same severity in a given year are also indicated - latter can be read from the secondary axis [2]. The figure shows that the number of fatalities on motorways and their proportion to all road traffic fatalities have continuously increased in the recent years, while the number and proportion of serious and slight accidents have remained unchanged over the national average. In order to decrease the number of fatal accidents and the number of fatalities on the motorway network, a complex enforcement package should be elaborated. One possible element of this, is the implementation of the section control on roads affected by speeding.

From the viewpoint of the data, it should be emphasized that the total length of the Hungarian motorway network was $1509 \mathrm{~km}$ in 2018, which is less than $5 \%$ of the total national road network $(\sim 32.000 \mathrm{~km})$ but $10 \%$ of the fatal accidents happened on these roads. Based on the 2018 traffic data motorway network generated $\sim 33 \%$ of the total national traffic, while the length of motorways was only $4.7 \%$ of the total national road network [10]. Based on the traffic and accident data for 2018 it can be stated that motorways are much safer than other national roads, taking the volume of generated traffic into consideration. It is true despite the fact that there are proportionally more accidents on these roads considering the extent of the network (number of lanes are not taking into consideration). Proportion of accident / vehicle $\mathrm{km}$ is lower by one order of magnitude on motorways than on main roads. See details in Table 1.

$40 \%$ of the accidents on motorways can be related to the fault of the driver and within this cause the main reason is the inappropriate speed choice. It was a key factor in case of the fatal accidents on motorways even in 2017 and 2018. More than $50 \%$ of the fatal accidents were triggered by this phenomenon. Further detail about speeding can be seen on Figure 4 (number of accidents are indicated on the main axis, while proportion of the outcome are indicated on the secondary axis) [2]. 
Table 1. Accident indicators in 2018 (accidents / vehicle km)

\begin{tabular}{|c|c|c|c|c|c|}
\hline $\begin{array}{c}\text { Accident indicator } \\
\text { (accident / vehicle km) }\end{array}$ & $\begin{array}{c}\text { Fatal } \\
\text { accidents }\end{array}$ & $\begin{array}{c}\text { Serious } \\
\text { injury } \\
\text { accidents }\end{array}$ & $\begin{array}{c}\text { Slight } \\
\text { injury } \\
\text { accidents }\end{array}$ & $\begin{array}{c}\text { Sum of all } \\
\text { accidents }\end{array}$ & $\begin{array}{c}\text { Proportion of } \\
\text { the traffic (\%) }\end{array}$ \\
\hline Motorway network & $3.72 \mathrm{E}-09$ & $1.24 \mathrm{E}-08$ & $2.61 \mathrm{E}-08$ & $4.22 \mathrm{E}-08$ & 33 \\
\hline $\begin{array}{c}\text { Main roads (without } \\
\text { motorways) }\end{array}$ & $1.65 \mathrm{E}-08$ & $1.52 \mathrm{E}-07$ & $3.57 \mathrm{E}-07$ & $5.25 \mathrm{E}-07$ & 67 \\
\hline $\begin{array}{c}\text { National road network } \\
\text { altogether }\end{array}$ & $1.25 \mathrm{E}-08$ & $1.08 \mathrm{E}-07$ & $2.52 \mathrm{E}-07$ & $3.72 \mathrm{E}-07$ & 100 \\
\hline $\begin{array}{c}\text { Prop. of the motorway and } \\
\text { national road network in } \\
\text { case of the accident } \\
\text { indicator }\end{array}$ & $29.8 \%$ & $11.5 \%$ & $10.3 \%$ & $11.3 \%$ & \\
\hline $\begin{array}{c}\text { Prop. of the motorways and } \\
\text { non-motorways in case of } \\
\text { the accident indicator }\end{array}$ & $22.5 \%$ & $8.1 \%$ & $7.3 \%$ & $8 \%$ & \\
\hline
\end{tabular}

Number and outcome of accidents happened on the Hungarian motorway network between 2010 and 2018

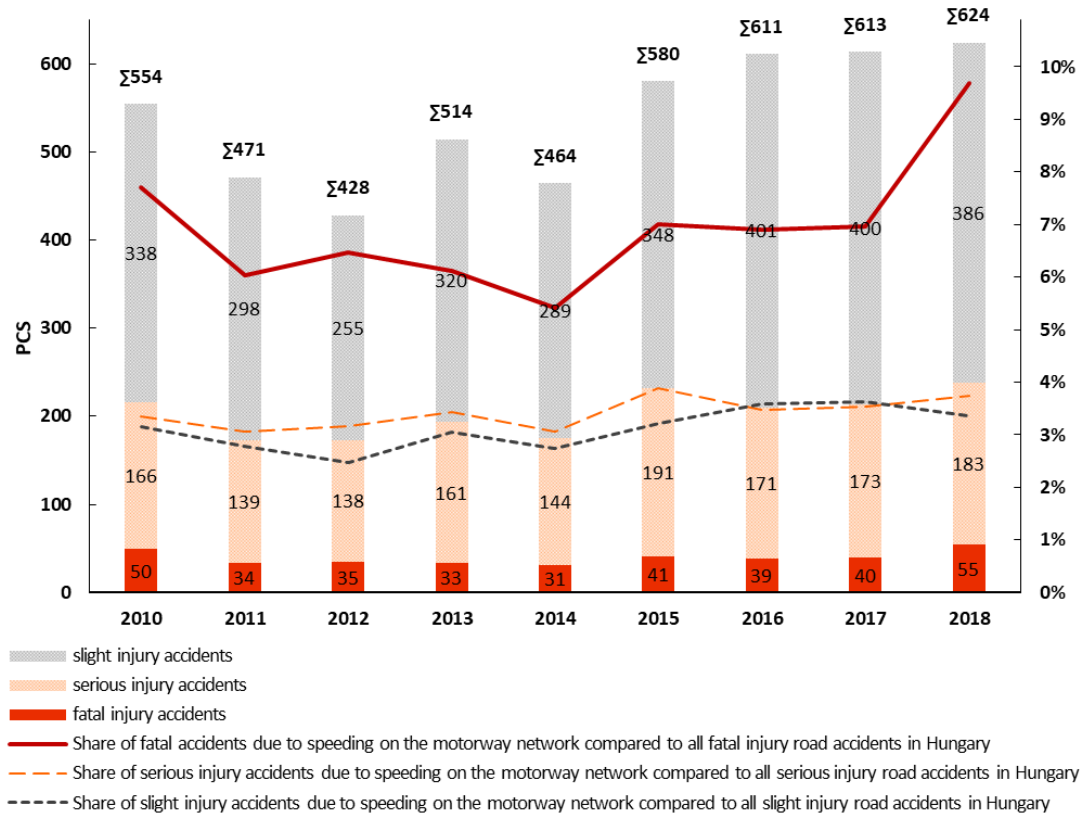

Figure 3. Accidents happened on the Hungarian motorway network 2010-2018. 


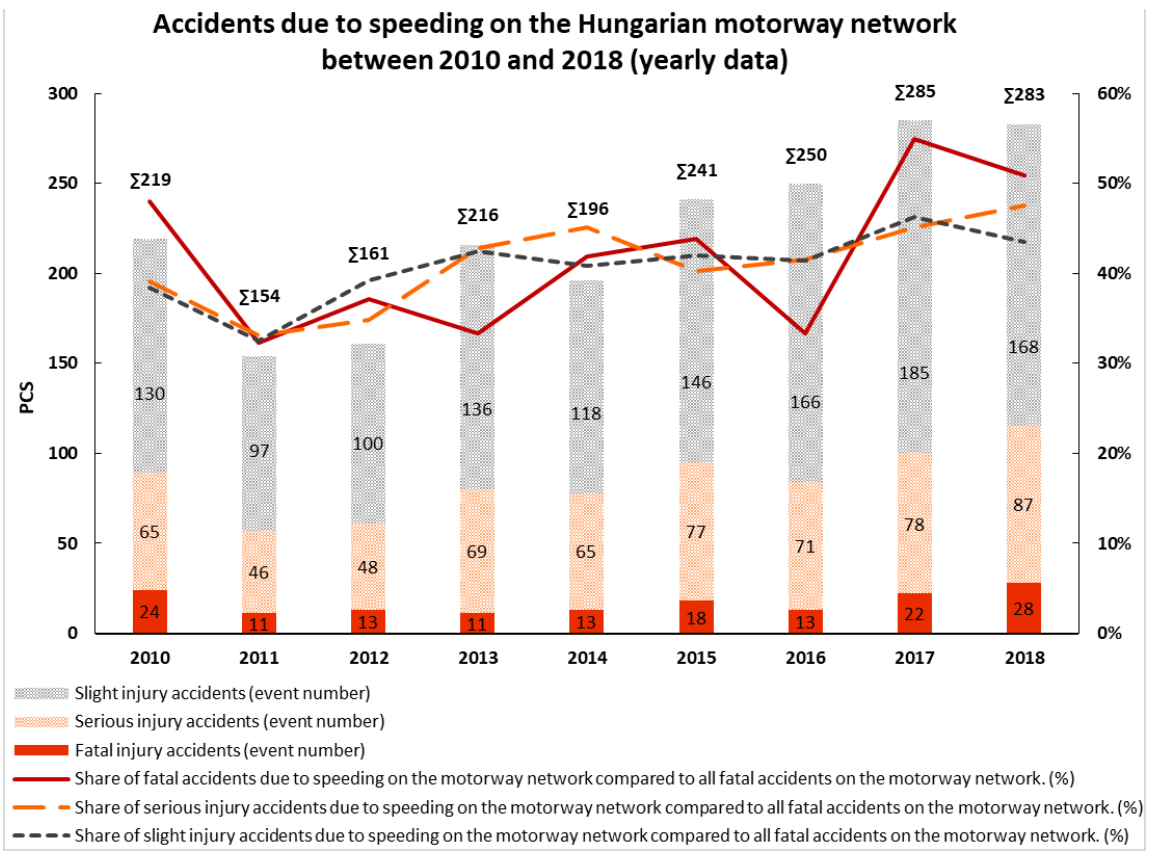

Figure 4. Speeding caused accidents on the Hungarian motorway network 20102018.

\section{Economic impact of the changes of road accident rates}

\subsection{Calculation method}

Estimating the effects of section control measurements on accident numbers can be quantified relatively easily. Based on international results and the Hungarian accident statistics it is possible to predict the expected development in the number of accidents and injuries on the sections affected by the measurement. Moreover country-specific accident costs are also available which show the social / economic costs of road accidents by outcome [11], [12], [13]. Most of the time costs are derived from the Statistical Value of Life (SVOL) by estimation in proportion to the GDP. It is important that value of human life is unique and unrepeatable, thus it conceptually differs from money. Monetary values that attempt to express this value are only intended to provide comparison for cost / benefit analysis of road safety measures and are not to be confused with insurance or court practice values. Values are express the value of one victim (one single person) or an accident. In the study the cost of a single person will be noted as the statistical loss value of the victim 
involved in the accident and the cost of a single accident will be noted as accident cost.

Hungarian and international guidance materials show different road accident cost values due to differences in calculation methodology and the differences in the use of the indicators. Values that used in this study were determined by the Hungarian Institute for Transport Sciences Non-profit Ltd. based on the guidance of the SfetyCube project and own calculation method [14]. Results of this study were calculated by the cost values given for 2017 due to the missing values for 2018 (Table 2). According to the method, cost values were increased in proportion to the GDP in 2018, thus the possible social benefits may be higher than the calculated values.

Table 2. The statistical loss value of the victims

\begin{tabular}{|c|c|}
\hline \multicolumn{2}{|c|}{$\begin{array}{l}\text { The statistical loss value of the victim } \\
\text { involved in the accident } \\
\text { (million HUF* in 2017) }\end{array}$} \\
\hline Fatal & 273 \\
\hline Serious injury & 66 \\
\hline Slight injury & 6 \\
\hline
\end{tabular}

The Hungarian loss values are regarding to victims not to accidents, thus in order to quantify the values of accidents, the average number of victims per accidents were determined. Based on the data of the Hungarian Central Statistical Office average number of involved victims per road accidents were calculated according to the outcome of the accident (Table 3) [2]. Data after 2010 were used and during the calculation results were rounded down. Values were generated by the use of the total number of accidents and victims (overall accidents ignoring the root cases and the locations of the accidents) due to the fact that the motorway specific victim data were not available. Standard deviations of the data are between 0 and 0.04 .

Table 3. Average number of involved victims

\begin{tabular}{|c|c|c|c|}
\hline \multicolumn{4}{|c|}{ Average number of victim involved in a single road accident } \\
\hline $\begin{array}{c}\text { Outcome of the } \\
\text { accident }\end{array}$ & \multicolumn{3}{|c|}{ Average number of victims } \\
\cline { 2 - 4 } & Fatalities & Seriously injured & Slightly injured \\
\hline Fatal & 1.1 & 0.4 & 0.4 \\
\hline Serious injury & - & 1.1 & 0.3 \\
\hline Slight injury & - & - & 1.3 \\
\hline
\end{tabular}


Accident costs were calculated by multiplying the statistical loss values and the average number of injured victims. Specific accident cost values are indicated in Table 4.

\section{Table 4. Calculated accident cost values}

\begin{tabular}{|l|l|}
\hline \multicolumn{2}{|c|}{$\begin{array}{c}\text { Accident costs / accident } \\
\text { (million HUF in 2017) }\end{array}$} \\
\hline Fatal & 325.8 \\
\hline Serious injury & 74.2 \\
\hline Slight injury & 7.5 \\
\hline
\end{tabular}

During the calculation pessimistic estimation was used to evaluate the reduction in the number of accidents by the implementation of section control enforcement. Accident statistics of the motorway network of 2018 was the basis and only those events were involved where the cause was the inappropriate speed choice. The initial data that was used for the calculation is presented in Table 5.

Table 5. The number of motorway accidents related to speeding in 2018

\begin{tabular}{|l|l|}
\hline \multicolumn{2}{|c|}{$\begin{array}{c}\text { Number of motorway accidents } \\
\text { due to speeding (2018) }\end{array}$} \\
\hline Fatal & 28 PCS \\
\hline Serious injury & 87 PCS \\
\hline Slight injury & 168 PCS \\
\hline
\end{tabular}

From the viewpoint of section control measurements the National Toll Payment Service (NPTS) Plc. - operator of the toll enforcement infrastructure - can cover approximately $70 \%$ of the whole motorway network ${ }^{1}$ (based on the length of the sections between the control cross-sections). It is called "SC covered network". Due to the characteristic of the toll enforcement infrastructure the system is not closed, thus only those vehicles can be controlled that pass at least under two gantries during their journey. During the analysis, only the infrastructure of NTPS was taken into consideration, other enforcement infrastructure (like the VÉDA system of the Police) was not due to legal consideration.

From the control point of view, in order to identify the scale of the potential traffic, it was examined that what proportion of traffic was appeared at least under two adjacent gantries compared to the total detected traffic. It is called "SC traffic". Analysing all passes of the year 2018, 61\% of the total traffic of D1 vehicle class

\footnotetext{
${ }^{1}$ The length of the current Hungarian motorway network is $1509 \mathrm{~km}$ (in August 2019).
} 
(passenger cars with the maximum capacity of 7 persons) appeared at least two adjacent gantries.

During the calculation of the possible changes in the number of accidents, a simplifying assumption was used: distribution of accidents on the motorway network was considered to be equipartition. Based on this, it can be estimated that the decrease of the number of accidents due to the implementation of the section control enforcement may be achieved in proportion of the coverage of the section control enforcement on the network. It means that the enforcement may affect $70 \%$ of the accidents happened in 2018. Due to the characteristics of the toll enforcement system (not closed), measurement may affect only those parts of the traffic that passes at least under two adjacent gantries. This proportion is approximately $60 \%$ of the total traffic (on average and rounded down), thus implementation of the section control enforcement can influence only a subset of all accidents. Number of influenceable accidents can be calculated by using formula (1) considering the simplifications mentioned above. Table 6 contains the results of the calculation. The determined values intentionally underestimate the real possibilities, as the distribution of traffic and accidents on the motorway network is not equipartition and the values have been rounded down.

Influenceable accident numbers according to outcome by applying section control measurements $=$ Accident numbers by outcome $(2108) \times S C$ covered network $\times S C$ traffic

Table 6. Number of accidents that may be influenced

\begin{tabular}{|c|c|}
\hline \multicolumn{2}{|c|}{$\begin{array}{l}\text { Number of influenceable } \\
\text { accidents by outcome due to } \\
\text { section control enforcement }\end{array}$} \\
\hline Fatal & $11 \mathrm{PCS}$ \\
\hline Serious injury & 36 PCS \\
\hline Slight injury & 70 PCS \\
\hline
\end{tabular}

Based on the results of international studies, three scenarios were elaborated for the accident reduction taking the effectiveness (magnitude) of the control measurement into consideration. In terms of fatal accidents, most studies reported $50 \%$ reductions in the number of accidents, while this proportion is around $35-55 \%$ in case of serious injury accidents and $20-40 \%$ in case of slight injury accidents. Table 7 shows each scenario and the related proportions. 
Table 7. Scenarios for accident number reduction

\begin{tabular}{|c|c|c|c|}
\hline $\begin{array}{c}\text { Impact on the } \\
\text { specific accident }\end{array}$ & Low & Medium & High \\
\hline Fatal & $-30 \%$ & $-40 \%$ & $-50 \%$ \\
\hline Serious injury & $-20 \%$ & $-35 \%$ & $-50 \%$ \\
\hline Slight injury & $-20 \%$ & $-30 \%$ & $-40 \%$ \\
\hline
\end{tabular}

\subsection{Results of the calculation}

Table 8. contains the social cost savings of the different scenarios that may be reached by the reduction of the number of accidents with the implementation of section control enforcement system. Calculation was based on the accident data of 2018 and it was made with the use of table 4., 6. and 7. Accident numbers were rounded down to integers.

Results were underestimated in all cases, and the potential effects may be even more significant, due to the applied simplifications. Moreover the monetized values are based on economic calculations from 2017.

Table 8. Social cost savings of the implementation of section control enforcement according to the different scenarios

\begin{tabular}{|c|c|c|c|c|c|c|}
\hline Magnitude & \multicolumn{2}{|c|}{ Low } & \multicolumn{2}{|c|}{ Medium } & \multicolumn{2}{|c|}{ High } \\
\hline & PCS & $\begin{array}{c}\text { social costs } \\
\text { (million HUF) }\end{array}$ & PCS & $\begin{array}{c}\text { social costs } \\
\text { (million HUF) }\end{array}$ & PCS & $\begin{array}{c}\text { social costs } \\
\text { (million HUF) }\end{array}$ \\
\hline Fatal & 3 & 977 & 4 & 1303 & 5 & 1629 \\
\hline Serious injury & 7 & 519 & 12 & 890 & 18 & 1336 \\
\hline Slight injury & 14 & 105 & 21 & 158 & 28 & 211 \\
\hline Total & & $\mathbf{1 6 0 2}$ & & $\mathbf{2 3 5 1}$ & & $\mathbf{3 1 7 5}$ \\
\hline
\end{tabular}

Changes in the accident data can be estimated with the application of the Nilsson power model too [15], [16]. The model (2) establishes a relationship for the evaluation of accident rates ( $\mathrm{Y}_{0}$-initial number of accidents, $\mathrm{Y}_{1}$-accident number after the measurement) for two different periods with different average speeds ( $\mathrm{v}_{0^{-}}$ initial average speed, $\mathrm{v}_{1}$-speed of the prediction period or the measured speed after the implementation of a specific measurement). The power factor $(\mathrm{k})$ is different according to the outcome of the accident and the type of road (rural or urban).

$$
\frac{Y_{1}}{Y_{0}}=\left(\frac{v_{1}}{v_{0}}\right)^{k},
$$

A few studies dealt with the relationship of speeds and number of accidents in Hungary. Based on the research the power factors of the Nilsson model had 
determined for Hungarian roads [17], [18]. The Nilsson model can estimate the possible changes in the number of accidents only in a specific speed range (25-120 $\mathrm{km} / \mathrm{h}$ ) [19]. Due to the higher Hungarian average speed values on motorways (they are over $120 \mathrm{~km} / \mathrm{h}$ ), it was not possible to use the model for the calculations of the possible effects.

\section{Further social and economic effects}

Positive economic effects can be direct or indirect. Direct economic effects - from the viewpoint of the current enforcement - are those, which provide immediate revenue for the public finance. These are the fines that can be imposed on speeders. It should be take into account that these revenues are only a single income, because drivers will take care of the speeds after the implementation of the enforcement system (or after the first fine has been imposed). International experiences show that after the implementation of these enforcement systems, less than $1 \%$ of the total traffic exceed the maximum speed limit. Direct fine income is depending on the tolerance range and the amount of the fine connected to the speeding range. It is important that the primary purpose of such control systems is not to increase fines but to improve road safety, so the evaluation of fines was not investigated.

Indirect positive economic effects will result in long-term benefits by reducing the externalities of road transport, which have large-scale social benefits:

- Reduction in emissions (pollutants, fuel consumption, noise, etc.): A distinction can be made between primary (vehicle owners and operators, people living next to the road infrastructure) and secondary stakeholders (residents who are not directly affected by the emissions - e.g. people far away the infrastructure).

Depending on the engine type and fuel (diesel oil / gasoline) every $10 \mathrm{~km} / \mathrm{h}$ increase in the speed, over $130 \mathrm{~km} / \mathrm{h}$ increases fuel consumption by 10 $25 \%$. The emission of pollutants also increases as the speed increases, in proportion to the consumed amount of fuel.

- Due to the homogeneity of the speeds, the traffic flow becomes more stable, which reduces the number of unnecessary brakes and accelerations, which leads to further fuel savings, thus reducing the negative environmental impact.

- Reduction of congestion that contributes to the travel time savings connected to accidents. 


\section{Conclusions}

The implementation of section control enforcement was analysed from the aspect of accident costs in the article. An estimate was made about the proposed accident effects based on the international experiences and the Hungarian traffic and accident data. The social cost of the expected change in accident numbers was analysed in detail and three different scenarios were elaborated taking the magnitude of the impact into consideration. The proposed magnitudes were based on international studies.

The focus was on the motorway network which is covered by the toll enforcement infrastructure of the National Toll Payment Service Plc. Infrastructure of other enforcement agencies were not taken into consideration due to legal issues.

The social benefits of the decreasing number of accidents are commensurate with the implementation costs of a control system. By the implementation of the enforcement system several lives can be saved. In all cases, the estimated results approach the real possibilities from the bottom up, as many simplifications were applied, and cost increase in proportion to GDP was not calculated. The advantage of the section control measurement system is that the coverage of the inspection network can be increased by installing new portals along the motorway network. Thus the expected social savings can be increased. The benefits of the proposed system may be greater than the indicated values in this article, because new motorway sections were opened in 2019, where new enforcement portals were implemented, thus the covered network has grown.

\section{References}

[1] Zs. Sándor, Á Monostori, Traffic Analysis of Specific Motorways with Different Usage Characteristics in Hungary with the Method of Section Control. Acta Technica Jaurinensis 13 (3) (2020) pp. 211-245. doi: https://doi.org/10.14513/actatechjaur.v13.n3.554

[2] Hungarian Central Statistical Office, 2019, official data publication

[3] A. Ragnøy, Automatic section speed control. Results of Evaluation. Norwegian Public Roads Administration, Directorate of Public Roads, Oslo, 2011.

URL http://hdl.handle.net/11250/2577051

[4] C. Stefan, Section control - automatic speed enforcement in the Kaisermühlen tunnel (Vienna, A22 Motorway). Austrian Road Safety Board (KvF), Vienna, 2006. 
[5] A. Montella, B. Persaud, M. D'Apuzzo, L. Imbriani, Safety evaluation of automated section speed enforcement system. Transportation Research Record (2281) (2012) pp. 16-25.

doi: https://doi.org/10.3141/2281-03

[6] E.W. Korthof, Effects of section control on traffic safety at Dutch motorways, Master thesis, Delft University of Technology, 2014.

URL http://resolver.tudelft.nl/uuid:261d7c62-a784-473c$98 b 6-85 a b e 72 f f d 33$

[7] D.W. Soole, J. Fleiter, B. Watson, Point-to-Point Speed Enforcement (APR415- 12). Centre of Accident Research and Road Safety - Queensland, 2012.

[8] D.W. Soole, B.C. Watson, J.F. Fleiter, Effects of average speed enforcement on speed compliance and crashes: A review of the literature, Accident Analysis and Prevention 54 (2003) pp. 46-56.

doi: https://doi.org/10.1016/j.aap.2013.01.018

[9] A.K. Høye, Evaluation of the crash effects of section control. Institute of Transport Economics Norwegian Centre for Transport Research, 2014.

[10] Cross-sectional traffic of national roads for 2017. Hungarian Public Road Nonprofit Private Limited Company Budapest, 2018.

[11] W. Wijnen, W. Weijermars, W. Vanden Berghe, A. Schoeters, R. Bauer, L. Carnis, R. Elvik, A. Theofilatos, A. Filtness, S. Reed, C. Perez, H. Martensen, Crash cost estimates for European countries, Deliverable 3.2 of the H2020 project SafetyCube, Belgium (2017)

[12] Methodology Guide for Cost-Benefit Analysis of Transport Projects (Hungarian: Módszertani útmutató egyes közlekedési projektek költséghaszon elemzéséhez). Ministry of National Development, Hungary (2016)

[13] T. Sipos, Determination of statistical value of life in case of slight injury accidents. (Hungarian: Könnyü sérülés statisztikai veszteségértékének meghatározása), Institute for Transport Science, research report, Budapest (2019)

[14] P. Holló, T. Sipos (2019). URL

http://kozlekedesbiztonsag.kti.hu/kozuti-balesetivesztesegek-aktualizalasal 
[15] R. Elvik, The Power model of the relationship between speed and road safety, TOI report 1034/2009, Norway, 2009.

[16] G. Nilsson, Traffic safety dimensions and Power model to describe the effect of speed on safety, doctoral thesis, Lund Institute of Technology Lund, 2004 URL http://Iup.Iub.Iu.se/record/21612

[17] P. Holló, O. Zsigmond, Road safety impact assessment of increased speed limits by trend analysis (Hungarian: Emelt közúti sebességhatárok közlekedésbiztonsági hatásvizsgálata idősorok elemzésével. Közlekedéstudományi Szemle 55 (3) (2005) pp. 90-95, in Hungarian.

[18] T. Mocsári, The examination of the average speeds and accident numbers based on national data. (Hungarian: Az átlagsebesség-balesetszám összefüggés vizsgálata hazai adatok alapján). Útügyi Lapok 1 (1) (2013) pp. 44-59, in Hungarian.

[19] R. Elvik, P. Christensen, A. Amundsen, Speed and road accidents: An evaluation of the Power Model (TØI report 740/2004). Institute of Transport Economics. Norway, Oslo, 2004.

URL https://www.toi.no/getfile.php?mmfileid=1007 